\title{
The ultimate miracle? The historicity of the Resurrection of Jesus
}

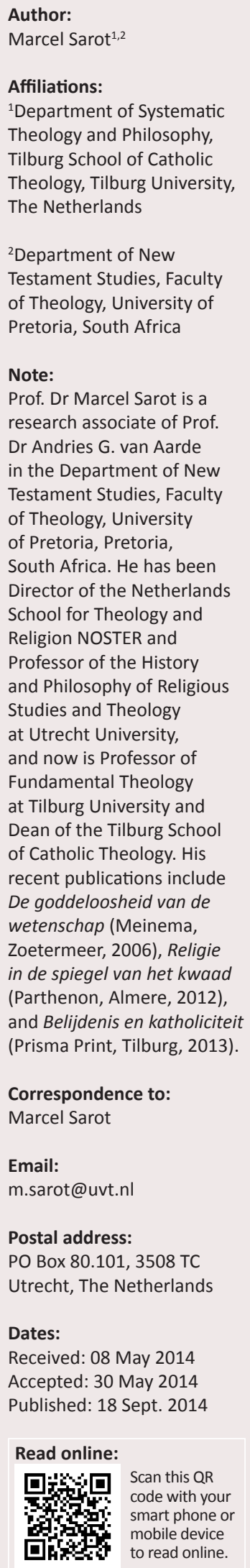

This contribution compares two views of the Resurrection of Christ; a traditional view that assumes that at the Resurrection, the dead body of Christ was transformed with the result that after the Resurrection, the grave was empty, and a revised view that assumes that the grave was not empty and that the Resurrection of Christ is not something that happened in this world, but in heaven. On the basis of a consideration of arguments for and against both views, the author argues for the traditional view. He goes on to show, however, that the traditional view cannot be adopted by historians who apply the principle of analogy. He argues, moreover, that this principle cannot be abandoned altogether. In the case of alleged singular events or miracles, however, this principle cannot be applied. This means that even if, as the author argues, the Resurrection is Geschichte (it really happened in this world, and the grave was empty), it falls outside the scope of Historie (it cannot be ascertained by the methods of strict historiography).

\section{Introduction}

If Christ has not been raised, our preaching is useless and so is your faith. More than that, we are then found to be false witnesses about God, for we have testified about God that he raised Christ from the dead. (1 Cor 15:14-15a NIV)

For Paul, it was clear: With the Resurrection ${ }^{1}$ of Jesus, the reliability not only of his own preaching, but of the whole of our Christian faith stands or falls. This is a strong claim, and Paul makes it about the Resurrection only, not about any of the other miracles that we find in the New Testament. In this, Paul is not alone. In the early Church, Jesus' Resurrection 'becomes the ultimate miracle in the series of miracles that marks his earthly ministry' (McGuckin 2004:293; cf. Aswin-Siejkowski 2009:63) and up to the present day, belief in a bodily Resurrection is often considered a litmus test for Christian faith.

In academic circles, however, this belief has lost much of its credibility; it is often claimed that a bodily Resurrection is scientifically impossible. Historical criticism came up with an alternative view of the Resurrection. This alternative view may be summarised as follows: In accordance with Jewish beliefs about the resurrection of martyrs, Paul, the earliest writer of the New Testament, held the opinion that three days after his death, Jesus rose and ascended to heaven in a new, spiritual body. The idea of the empty grave is a legend, composed by Mark, the first Gospel writer. He interpreted the original story about a Resurrection in heaven in Greco-Roman terms as a Resurrection of the earthly body: Just like Hercules, Aeneas and Romulus, Jesus ascended to heaven in his earthly body, leaving behind an empty grave (Philipse 2001, 2012:5, 173-175). This is not the view of a few eccentric biblical scholars and historians, but that of the academic establishment'. It is incompatible with the traditional faith in the Resurrection, which understands the Resurrection as the supreme miracle: He who was carried into the grave dead, walked out of it alive! Accepting the revised view means giving up a fundamental tenet of traditional Christianity. Therefore, it is not surprising that this revision has been met with criticism, both from 'ordinary believers' and from eminent theologians and philosophers. Wolfhart Pannenberg and Alvin Plantinga argue that the historicity of the Resurrection can be proven historically (Pannenberg 1967, 1994; Plantinga 2000:374-421).

Thus, we have on the one hand the 'critics' who claim that science disproves the empty grave and that the Resurrection was not of a bodily nature, and on the other, the orthodox who argue that it can be historically proven that a bodily Resurrection took place. Those who hold the critical

1.I write 'Resurrection' with a capital when I mean the Resurrection of Jesus.

How to cite this article: Sarot, M., 2014, 'The ultimate miracle? The historicity of the Resurrection of Jesus', HTS Teologiese Studies/ Theological Studies 70(1), Art. \#2721, 9 pages. http://dx.doi.org/10.4102/hts.v70i1.2721

Copyright: @ 2014. The Authors. Licensee: AOSIS OpenJournals. This work is licensed under the Creative Commons Attribution License. 
view like to suggest that whilst their view is rooted in the academy, the traditional view is rooted in the Church. This traditional view is then labelled as fundamentalist and as mirroring a mythical view of the world. Whilst there have been discussions between proponents of both views, mostly they exist parallel to each other without much contact. In the present contribution I will, as a systematic theologian with a background in the philosophy of science, try to show that a confrontation of both views can bring us further, and can show that this discussion is not a discussion between believers and scientists, but between alternative academic positions that both have strong and weak sides. In the end, I will reject both the traditional approach and the historicalcritical alternative, and argue for a middle position.

My contribution is structured as follows: Firstly, I will explain the concept of a miracle, because that is essential to my argument. After that, I will inquire what exactly happened at the Resurrection according to the traditional Christian faith. Consequently, I will explain why the Resurrection is of such fundamental importance to Christianity. Then again, I will rather extensively discuss the historical-critical reading of the Resurrection-stories, and I will argue why I prefer the traditional reading. Only then, when it is clear what is exactly reported in the Resurrection-stories, we can ask to what extent they are historical. I will discuss two objections against historicity, a Humean and a Troeltschean objection, and in discussion with those objections I will develop my own position.

\section{What is a miracle?}

Strictly speaking, one can only speak of a miracle when two conditions are met: (1) an event took place that cannot be explained by any known laws of physics, and even seems to contradict them (in scientific terms: an anomaly); (2) from a believers' point of view, this event can be understood as an intentional act of God (cf. Holland 1965). Miracles can be seen only with the eyes of faith! Imagine that, when I was taking a shower this morning, wine had come out of the shower head instead of water! That would probably have scared me. Imagine further, that closer investigation brought no meaningful explanation. We would then speak of an anomaly, and if these things would happen more often, we would say: 'We are haunted!' That is not our reaction to the wedding in Cana, where Jesus changed water into wine. There, we speak of a miracle, because we ascribe the anomaly to an act of God through Jesus, in answer to a request and with the purpose of helping the bridegroom (and at the same time making something clear about Jesus' mission). Both aspects, the anomaly-aspect and the intentional-act-of-God-aspect, are necessary conditions to speak of a miracle in a strict sense. On its traditional interpretation, the Resurrection is a miracle in the strict sense. For when a dead man comes to life, that is an anomaly, and with the eyes of faith this anomaly can be seen as an intentional act of God.

\section{Which facts are asserted when it is claimed that Jesus has risen?}

What is true when Jesus rose indeed, that would not be true if he had not risen? Whilst drawing on the Gospel narratives, I will ignore the narrative details of individual stories and focus on what they assert when taken together. At this stage, I will interpret the stories in a traditional way. Further on, I will discuss the credibility of the picture thus emerging.

No testimonies of the Resurrection itself have been handed down. Insofar as we know, no man has actually seen Jesus rise. There are testimonies of the empty grave and of apparitions of the risen One, from which the Resurrection can be deduced, but that is it. Traditional Christianity makes no factual claims about the 'technical' or 'biological' side of the Resurrection, or about the exact moment of its occurrence; all of these remain in the dark. That Jesus has risen means that:

1. Jesus, who had died, has come to life. After the Resurrection, we can no longer say of Jesus: He is dead. We must now say: He is alive! (cf. Rom 6:10; Rev 1:18, 2:8). He who was carried into the grave as a corpse, walked out of it as a living man.

That Jesus has risen also means that:

2. After the Resurrection, Jesus' grave was empty. The story of the empty grave is part of all four Gospels. Matthew provides the most detailed account: He reports how Pilate had the grave guarded, but the guards were stricken by unconsciousness during the Resurrection itself. From the empty grave it can be inferred that the risen body of Jesus was created from his mortal remains. During the Resurrection, Jesus' corpse was brought to life. The continuity between Jesus' pre-Resurrection body and his post-Resurrection body is emphasised, for example, in the story of the doubting Thomas. Here, it is made clear that the resurrected body is material (Jn 19:20, 24-29; see also Lk 24:39-40) and carries the marks of the crucifixion. Paul also emphasises this continuity when he compares the dying body with a seed (1 Cor 15:36-38), and the resurrection with its sprouting. At the same time, the discontinuity is hereby stressed, because a seed is not identical with a full-grown plant. In summary:

3. Jesus' resurrected body is shaped by a transformation of his earthly body and there is both continuity and discontinuity between the two. It is because of the continuity that we have to deal with a Resurrection, for the term presumes something that rose. And it is because of the discontinuity that the Resurrection of Jesus differs from earlier resurrections, because in these cases the body that rose was identical with the pre-resurrection body, and there was no remarkable discontinuity between preresurrection and resurrection body. Both continuity and discontinuity are asserted appearance narratives in the Gospels. There are many of these, scattered over various books by various authors. I conclude:

4. After the Resurrection, Jesus appeared to many people. Of course, much more is to be said about the Resurrection. 
The above suffices, however, for scrutinising the historicity of the Resurrection.

The aspects (1) and (3) concern what happened at the Resurrection (Jesus, who was dead, came to life, whereby his mortal remains were transformed), whilst aspects (2) and (4) basically concern the empirical data: The grave was empty, and Jesus appeared to many.

\section{What is the importance of the Resurrection?}

Paul is not the only one to emphasise the importance of the Resurrection. Most Christians agree that whilst some biblical miracles may be understood symbolically and remain meaningful even if they did not actually happen, this does not apply to the Resurrection. Symbolic interpretations of the Resurrection have been attempted: The Resurrection narratives would in fact concern the experience of God's forgiving grace by Jesus' disciples after his death (e.g. Schillebeeckx 1979), or the experiences of community that Jesus' disciples had after his death (Veldhuis 1978). Such interpretations meet with two important objections. Firstly, it seems that at the crucifixion not only the disciples abandon Jesus, but God does the same. Jesus is God-forsaken. It is not until the Resurrection that it becomes clear that God did support Jesus through it all: In and through the Resurrection, God rehabilitates Jesus. If the Resurrection was an experience of his disciples, more than of Jesus, the Resurrection would not rehabilitate him.

Secondly, God asserts His ultimate power in the Resurrection. Human beings can bring Jesus into the grave, but they cannot keep Him there. God's non-intervention at the crucifixion did not spring from powerlessness. In this manner, the Resurrection inspires hope: hope for the resurrection of individual Christians after death (cf. 2 Cor 4:14, 1 Th 4:14, Rev 1:18), and hope for the transformation of creation, a new heaven and a new earth, at the end of times (cf. Ac 17:31). Without the Resurrection, we would have no ground to believe that God would be able and willing to intervene in the eschaton.

Thus, the veracity of the Resurrection is the guarantee for (1) the reliability of Jesus as God's chosen messenger and (2) the conviction that God has control over the lives of individual persons and over the course of history, even when this control is not apparent.

\section{The historical-critical interpretation of the Resurrection narratives}

In the aforementioned, I have argued on the basis of New Testament texts that after Jesus had risen, his grave was empty. This empty grave is an empirical aspect of the Resurrection that can be scrutinised by empirical research. Contemporary historical-critical approaches, however, suggest a different reading of these texts. They suggest that if one reads the New Testament well, one would understand that the empty grave narratives do not describe a historical reality. The New Testament Resurrection narratives stem from various authors who wrote at different times. The most recent stories are several decades younger than the oldest stories. Moreover, they contain 'contradicting reports' that are not easily harmonised. Henk Jan de Jonge provides a useful summary of this critical view:

The older documents, especially Paul's, take Jesus to be raised and assumed into heaven without presupposing that his earthly body has left the grave ... Only the later documents, from 70 A.D. and onwards, tell stories about people who found Jesus' grave empty ... This story, by Mark [whose Gospel is then dated around 70] and adopted by Matthew and Luke, ... was until the years 60-70 less widely spread than were the reports about Jesus' resurrection without an empty grave ... Here, the historian will have to choose, and will without any trouble choose for the older conception. There are two additional reasons for this. Firstly, because the conception without the empty grave also occurs in a document independent from Paul, namely the letter to the Hebrews ... Consequently, it can be shown that it belongs to the conceptions that circulated in the Church before and parallel to Paul's: The resurrection without the empty grave is truly the oldest ascertainable conception. Secondly, this conception is less adapted to heathen conceptions ... and it seems therefore less attuned to the new circumstances in which the gospel was preached later on. (De Jonge 1989:33, [my translation])

The empty grave would thus be a later addition of legendary nature to the Resurrection narratives. It was introduced to facilitate preaching the Gospel among the gentiles. Three elements in De Jonge's argument need further clarification: (1) The position of Paul, (2) the position adopted in the Letter to the Hebrews and (3) the gentile conceptions that De Jonge mentions.

Concerning the position of Paul, De Jonge refers to 1 Corinthians 15. De Jonge observes that even when Paul wanted to prove the resurrection from the dead and used Jesus' Resurrection by way of analogy, 'the idea did not occur to Paul to supply the best possible proof, namely the fact that it had been established that Jesus' grave was empty' (1989:34). Furthermore, nothing suggests, according to De Jonge, that Paul conceived of the Resurrection as a return to earth: (1) He conceives of the risen one as existing in heaven (1 Cor 15:48-49), (2) he nowhere mentions an interim state between Jesus' Resurrection and his entering heaven and (3) he does not mention the Ascension.

De Jonge (1989:33) is brief about the position adopted in the Letter to the Hebrews: He refers to three texts (5:8-10; 9:11-12;12:2-3) where the letter speaks about the Resurrection without mentioning the empty grave or an interim state between Jesus' Resurrection and his Ascension.

Finally, I want to comment briefly on the alleged pagan influence on the empty grave stories. According to De Jonge, a number of ancient writings claim of various persons that they would have ascended to heaven; in their cases also, their 
empty graves were supplied as proofs (1989:44). In the oldest and most reliable stories of Jesus' Resurrection, his body remained in the grave: The Resurrection was physical, but only in the sense that Jesus had a new Resurrection body. The stories of his appearances served as proof. Only later, under the influence of the just-mentioned parallels, the original conception was modified and stories about the empty grave were introduced as a proof of the reality of the Resurrection.

De Jonge's approach to the Resurrection is typical of the mainstream position in today's critical exegesis. On this view, no miracle took place. In what De Jonge calls the 'original view of the resurrection', the Resurrection did not take place in this world. Jesus' corpse remained in the grave, and the Resurrection took place in a world beyond this one. If that is what the texts imply, it is clear that no part of the Resurrection-stories could be subject to historical scrutiny.

To what extent is this critical approach to the Resurrection plausible? Let us, for the sake of argument, accept the usual dating of the historical-critical exegesis. Then Paul is indeed the first author who speaks of the Resurrection. Do Paul's views differ that much from those of the Gospels? It is correct that Paul does not explicitly mention the empty grave, the period between Resurrection and Ascension, and the Ascension itself. If we had no other source but Paul, our view of the Resurrection would probably be much different from the traditional view. We do, however, have the Gospels as well. Thus we should ask the question: How are the data from the Gospels and from Paul's letters related?

In answering this question, we must beware of the fallacy called argumentum e silentio (argument from silence) in logic (cf. Craig 1985:40-42; Kretzmann 1993:145). This fallacy appears in two forms: (1) conclusion to a statement on the basis of its absence in the argumentation; (2) conclusion to a denial of the same statement on the basis of the same absence. On the basis of the absence of a statement in an argument, one could draw two diametrically opposed conclusions: The statement may either be so obvious for the author that he sees no need of explicitly mentioning it, or it may be unknown to him or he may view it as of no importance. The fact that diametrically opposed conclusions can be drawn from an author's silence should make us hesitant to draw conclusions from silence alone. Applied to the Resurrection: On the basis of the fact that Paul fails to speak explicitly about the empty grave, one can either conclude that Paul did not know of this tradition or judged it to be unreliable, or that he considered it so well-known that he did not judge it necessary to mention it.

If we want to know which of the two it is, we must look for other clues in Paul's letters. This is exactly what De Jonge does, when he draws attention to the fact that Paul mentions neither an intermediate state between Resurrection and abidance in heaven, nor an Ascension. Instead, he viewed the risen one as existing in heaven (1 Cor 15:48-49). The arguments about the interim state and the Ascension, however, are again arguments from silence. Here again, it is difficult to draw unambiguous conclusions. This, however, does not count for the last argument: That Paul speaks about the risen Christ as existing in heaven. De Jonge concludes from this: 'To Paul, resurrection and elevation are one and the same. The risen one is the heavenly one' (1989:34). Thus, there was no empty grave, no interim period, and no Ascension.

I have three comments to make on this. Firstly, Paul may not explicitly mention the empty grave, but he does seem to suppose it when writing that Jesus 'was buried, that he was raised on the third day according to the Scriptures' (1 Cor 15:4 NIV). This remark can hardly be understood if Paul was not aware of the tradition about the empty grave, because then it could not be known when Christ had risen (Neill 1964:287; cf. Pannenberg 1994:324-325). Secondly, it must be said that although Paul qualifies the risen body as heavenly, he emphasises in the same chapter not only the discontinuity but also the continuity by calling the earthly body a seed which God raised (in a transformed mode) in the Resurrection. A plant originates from a seed, and the seed itself cannot be found after germination. When we apply this metaphor to the Resurrection, it suggests that Jesus' risen body originates from his earthly body, and that his earthly body can no longer be found after the Resurrection. Finally, 1 Cor 15:3-8 also mention some of Jesus' appearances. Given that these took place on earth, an interim period during which Jesus appeared on earth several times was not unknown to Paul. The least to be said is that for Paul, Jesus was not locked up in heaven after the Resurrection. Paul's view here appears to be in line with that of the Gospels: Whilst telling stories about Christ's appearances, these nowhere suggest that Jesus remained permanently on earth between Resurrection and Ascension.

Thus, Paul did hint at an interim period and seems to presuppose the empty grave. Altogether, there seems to be little reason to outplay Paul's reticence on certain issues against the conceptions of the Gospels so as to make them incompatible. Moreover, the difference in emphasis between Paul and the Gospels may in part be explained by differences caused by genre. The Gospels tell a story about Jesus' life, death and Resurrection, and so they relate the events in a plausible order: death, funeral, Resurrection, empty grave, appearances and Ascension. Paul does not write a story but argues, twenty years after the events, from his own experience. The empty grave is not a part of his experience, but an appearance of the risen Christ is, although it took place after the interim period. Viewed in this light, the differences between Paul and the Gospels are not remarkable.

One last argument deserves brief attention, namely that of parallel empty grave narratives from pagan antiquity. If it had been proven that the empty grave narratives were legendary later additions to the original Resurrection narratives, these parallels might perhaps provide a motive for their addition. However, now that it is insufficiently plausible that the empty grave narratives stem from a later tradition, contemporary parallels add little to the probability of this 
hypothesis. The fact that narrative motives appear in legends does not mean that the same motives cannot be explained in factual accounts. Some people do in fact live 'happily ever after'. Moreover, the best-know parallel, that of Jesus' contemporary Apollonius of Tyana (Ehrman 2012:208), dates from a 3rd-century source. If there has been influence, it was the Gospels that influenced Philostratus's Life of Apollonius of Tyana, not the other way round.

Does the New Testament imply an empty grave or not? When we compare the 'critical' reading of De Jonge c.s. to the 'naive' reading I provided earlier, the picture remains ambiguous. On the one hand, the 'critical' hypothesis (i.e. there was no empty grave) seems to be a fruitful working hypothesis. If we start from this hypothesis, the data allow themselves to be interpreted in terms of a historical development from stories about appearances to stories about the empty grave. Moreover, the hypothesis also provides grounds for this development. But if we do not begin with the hypothesis that the grave was not empty, the New Testament in no way makes this hypothesis necessary. The texts can without difficulty be read as a more or less consistent and coherent report of a Resurrection with an empty tomb.

This leads to a difficult dilemma: Both the traditional and the historical-critical interpretation of the texts seem to be corroborated by further investigations.

\section{How do we choose between two views of the Resurrection?}

At first sight, I have a slight preference for the traditional view because it meets with fewer problems than the revised one. In the absence of evidence, it is highly unlikely that Paul's view of the Resurrection differs that much from that of the Gospels. Paul mentions a period during which Christ appeared to his followers, the 'interim period', he asserts that Christ had risen 'on the third day', and he emphasises the continuity between the earthly and the risen body in such a way that an empty grave seems to be implied. Prima facie, the traditional interpretation of Paul seems to have the best papers.

This slight preference is strengthened by the following considerations. Firstly, the view that miracles are physically impossible plays an important role in the background of the rejection of the traditional interpretation. The spirit of Rudolf Bultmann is still among us: 'It is impossible to use electric light and the wireless ... and at the same time to believe in the New Testament world of spirits and miracles' (Bultmann 1961:5). The problem with this view is that it misunderstands the nature of natural laws: Laws of nature are conditional in nature. The grass in my yard will, for example, grow longer unless I mow it; the stone I throw at a window will smash it unless it is caught by someone, and so forth. Laws of nature describe how things will happen and how processes will take place in the absence of intervention (Hansson 1991:100-103; Nienhuis 1995:50). Free acts are among possible interventions. Traditional Christian faith upholds that free agency is not limited to human beings; God is the supreme Actor. If human free actors can intervene in the chain of cause and effect, and I suggest that this is a fact, why could a divine Actor not do the same? In short: Miracles as free acts of an invisible Actor cannot be a priori excluded. Thus, the argument from physical impossibility does not refute the traditional interpretation of the Resurrection.

A second consideration in favour of the traditional interpretation is that the critical interpretation doubts the sincerity of the Gospel writers. According to John Muddiman, the final verse of the Gospel of Mark: 'And they said nothing to anyone [about the empty grave] for they were afraid', has been explained as follows: Before Mark, the legend of the empty grave was not part of the Resurrection-stories. The writer of the Gospel of Mark made the story up, and inserted it into his Gospel. To explain why it was not known earlier, he said that the women remained silent out of fear. Even if Mark did not make up the story about the empty grave, but adopted it from an existing but less widespread tradition, the addition of this final sentence would be a deed of deceit. According to historical-critical exegetes, this is but one example of the ways in which the Gospel writers have attempted to give an aura of historicity to legendary material. In the absence of any hard evidence, however, assuming deceit seems neither a plausible nor a fair way to defend the historical-critical interpretation of the Resurrection (Muddiman 1989:6-7). We may add to this that, if the Gospels were overtly unreliable, it is most peculiar that they acquired so much authority in the early Church. For me, the alleged insincerity of the Gospel writers is a strong argument against the critical interpretation of the Resurrection.

The previous arguments strongly confirm the traditional interpretation of the Resurrection-stories. Although belief in the Resurrection is not primarily about the empty grave, this does not mean that we can believe in the Resurrection without believing in the empty grave (Barth 1948:543). Many would argue, however, that even if this is a rational position for the believer, it is not for the historian. In the following, I will discuss two arguments against asserting the empty grave in historiography. According to the first argument (Hume), the improbability that a miracle like the Resurrection takes place more than cancels the strength of any witness which would lead us to accept it. According to the second argument (Troeltsch), historiography should accept methodological naturalism and thus a priori exclude divine intervention.

\section{Hume and the value of testimonies about the Resurrection}

In his On miracles, David Hume does not focus on the Resurrection. Nonetheless, he is still quoted in discussions on the Resurrection. The essence of his argument is: When we have not witnessed a miracle ourselves, we can never have sufficient reason to believe the testimonies of those who did witness it. Why not? I quote from the summary of Hume's argument by Herman Philipse (2001), a recent supporter of Hume: 
We must ask ourselves two things. How likely is it that the tradition that reports about the miracles is reliable? And how likely is it that the miraculous event itself took place? The second must be most unlikely; otherwise, the event could not be qualified as a miracle. Now the problem is that the improbability of the event about which a tradition reports, renders the credibility of that tradition unlikely. Therefore we can appreciate a tradition that reports about miracles only if we know on other grounds that this tradition is absolutely reliable. Hume formulates this difficulty as follows: We may only trust a tradition if the unreliability of that tradition is a greater miracle than the event which this tradition reports. (n.p.)

Of course, this requirement has never been met. Hume provides a whole list of factors, which should lead us to suspect such a tradition. All present-day testimonies about miracles that have been investigated scientifically have proven to be treacherous. People love strong stories and have a tendency towards superstition. Believing that we have witnessed a miracle boosts the ego: We have been chosen! Testimonies about miracles are always tainted by selfinterest. Moreover, they typically come from the uneducated (Philipse 2001).

This argument revolves around two factors: The improbability that the miracle took place and the suspected unreliability of the witnesses. Let us examine these two factors closer in connection with the Resurrection. How unlikely is it that Jesus rose from the dead? Here, it does not suffice to suggest that anomalies have been known to happen before. The Resurrection is not just any anomaly. It is not only claimed that a dead man has risen, but also that he has risen with a changed and transformed body. This claim is extremely rare and when atheists call this particularly improbable, they are correct.

Over against this, the reliability of the witnesses must be asserted. A number of arguments can be given. In the first place, we possess a great number of documents which report about the Resurrection. Those are the four Gospels, Acts and some letters; at least the oldest of these were written in a time when many eye-witnesses were still alive; according to the usual dating 1 Corinthians was written in 55 CE. Moreover, in these sources a great number of witnesses are mentioned by name. For an ancient event, the number of witnesses is conspicuously high, and they agree on key issues. In this case it can also hardly be held that the testimonies stem from uneducated people (Hume). Although early Christianity gained its following mainly from the lower classes, the New Testament writers made an important contribution to world-literature. And whilst the believer can explain this contribution from divine inspiration, this is no option to a secular historian. Secondly, it can be added that the first persecutions of Christians are already mentioned in the book of Acts. Both from Acts and from his own letters, we know that Paul was persecuted for his faith. If the first Christians had not been firmly convinced of the reality of the Resurrection, it seems improbable that they would have stood firm during the persecutions. The 'self-interest' suggested by Hume certainly plays no part here. Thirdly, the grave in which Jesus was laid is indicated very precisely: It was a new grave, it had not yet been used, it was hewn out of the rocks near Golgotha, and it belonged to Joseph of Arimathaea. This specific information renders the empty-grave-tradition controllable and it is a strong argument for its reliability.

When viewed from this perspective, the Humean argument against the reliability of witnesses of miracles do not convince in the case of the Resurrection. The probable reliability of the witnesses and the improbability of the event seem to balance each other out. Here, I suggest, historians are confronted with a deadlock. How they weigh the one against the other cannot be said beforehand. I would expect that for historians who themselves do not believe in God, the improbability of the event weighs heaviest. For historians who do believe, things could be different.

For believers, the anomalies that are interpreted as miracles are only seemingly anomalous. In reality they are no anomalies, but (effects of) free acts of God. Free acts lie at the origin of events that one would not expect on the basis of natural laws only. Just a moment ago, I switched on the light in the room in which I am writing. Viewed in isolation from my act, the sudden presence of light is an anomaly. My act, however, provides a good explanation for this event, and for that reason we do not speak of an anomaly here. For the believer, this also applies to the Resurrection, I would like to suggest. The believer sees the relation between the Resurrection of Christ and the acts of God as analogous to the relation between the sudden presence of light and my turning on the light. If we view it as an anomaly, the sudden presence of light is highly improbable, but this is not the case when it is understood as an act of an almighty God. In short: if one believes in God, the Resurrection loses its improbability and the probable reliability of the testimonies suffices to convince the believer that the Resurrection in fact took place.

Does this mean that historiographers who believe in God can assert the historicity of the Resurrection without problem? Ernst Troeltsch would deny this, because even historians who believe in God should in their historiographical work accept methodological naturalism. We will now discuss this Troeltschean objection.

\section{Troeltsch and the boundaries of historiography}

\section{On the level of theory, there is no room for the empty grave}

H.J. de Jonge (1989) explains Troeltsch's position as follows:

A strict historian can in principle not deem the report reliable that a dead man comes to life and leaves his grave, for such a resurrection would be wholly unique in nature and go against all known order. Something so peculiar in nature could only be rendered plausible to the historian if he had knowledge of a reliable analogy. Something strange will only be accepted when it can be compared to something familiar and understandable. Such an analogy, however, fails. Nobody knows a fellowhuman who has risen from the dead ... It is true that the just- 
mentioned strict approach sets a priori limits to the possible variation in history: For the essentially unique event, this type of historiography has no place. (p. 32, [my translation])

The principle sketched here by De Jonge, is known as Troeltsch's principle of analogy. This principle of analogy is in fact a variant of the principle that we explain the unfamiliar by the analogy with the familiar. It also works this way in historiography, according to Troeltsch: We attempt to understand history by means of analogies with the present (Troeltsch 1913:732-733). When we know that a certain phenomenon or a certain event always stems from a certain cause, we are no longer free to explain the same phenomenon in the past in a different manner. For example, we explain the fact that Jews in the Middle Ages suffered less from the plague than other groups from the fact that their observance of the Jewish law made them observe higher standards of hygiene than those that were common among Christians. From more recent research we know that hygiene is a crucial factor in preventing contagious diseases. We tend to exclude alternative explanations, like a pact with the devil, because we know of no analogous contemporary case in which a pact with the devil secures health.

Of course, the analogies by which we understand historical events are no unique events but 'mehrfach bezeugten Vorgangsweisen und Zuständen': 'patterns' which have been perceived more than once. For the essentially unique, historiography has no place. In light of the principle of analogy it is one of the two: Either the grave was not empty, or there is a natural explanation for the empty grave. Since there is no natural explanation in this case - to my knowledge there are no serious historians who defend the hypothesis that the corpse was stolen to explain the empty grave - the only hypothesis left is that the grave was not empty. That does not complete the activity of the historian, for a new fact is to be explained: If the grave was not empty, how can it be that so many witnessed to its emptiness? As we have seen, the principle of analogy allows for a natural explanation: The stories about the Resurrection have developed from appearance narratives to empty grave narratives. Previously, I have rejected this explanation because it fails to make sufficiently clear how a fairly large group of seemingly reliable witnesses came to assert false and even deceitful testimonies. The critical explanation thus sins against the principle of sufficient ground: An explanation of a certain phenomenon is successful only if it specifies the sufficient conditions for the occurrence of this phenomenon. In the case of the presumed deceitfulness of the testimonies about the empty grave, the critical hypothesis fails to do this. Must we then assume that these testimonies are true?

Here again, critical historiography is confronted with a deadlock. On the one hand, the principle of analogy leads to the hypothesis that the grave was not empty, on the other hand the principle of sufficient ground leads to the conclusion that the testimonies about the empty grave are reliable. Yet, if the testimonies are reliable, the grave was empty; and if the grave was not empty, the testimonies were not reliable. How can we avoid this aporetical position?

\section{Conclusion}

\section{The principle of analogy, Geschichte, Historie and the Resurrection}

One solution to our problems is that we criticise the principle of analogy itself, so that it can no longer be positioned against the historicity of the empty grave and the Resurrection. Wolfhart Pannenberg adopts this strategy when he states that the power of an analogy lies in perceiving the equal in the unequal. He argues that analogies may never be used in such a manner that the unique and individual are excluded. Concerning the Resurrection, Pannenberg (1967) states the following rhetorical questions:

Is not the postulate of the fundamental similitude of all that takes place ... taken to be the main argument against the historicity of the resurrection of Jesus? Does this not mean that the conception that the resurrection of Jesus cannot be an historical event, which has become almost self-evident, is remarkably ill-based? (p. 53, n. 22)

And he replies:

Only the nature of the reports makes possible a judgment about the historicity of the resurrection, not the prejudice that all that happens must be of a fundamentally similar nature. (p. 53, n. 22)

Pannenberg (1967) suggests that the principle of analogy sets limits to what can and what cannot take place in reality: '[A]ll that happens must be of a fundamentally similar nature'. If this was the case, the principle of analogy should indeed be rejected. The principle of analogy, however, does not regard what can happen in reality, but what can be ascertained by the methods of strict historiography. If the principle of analogy makes it impossible for historians to ascertain that the grave was empty or that Jesus has truly risen, this does not mean that the event did not take place. In traditional Christianity the Resurrection is a unique event. Troeltschean historiography a priori excludes that we conclude to unique events. Therefore, it is an instrument unfit to answer the question whether they in fact took place.

The possibility that events may occur which in principle cannot be ascertained by historiography may for some be disquieting. Yet there are good reasons not to give up the principle of analogy. The most important reason is this one: Once one lets this principle go, anything goes. Any explanation, however improbable, would become acceptable. We know, for example, that among human beings a woman's pregnancy is caused by male sperm; we do not know of exceptions to that rule. To the strict historian, who makes use of the principle of analogy, this means that alternative explanations, which are without analogy (the stork, the Holy Spirit) are excluded. Once historians would admit these explanations, there would be no end to possible explanations. Even explanations like 'I have eaten a peanutbutter sandwich' and 'I thought of a man' would become acceptable.

The problem we face has now been sketched in all its acuteness. We cannot reject the principle of analogy with 
Pannenberg. But acceptance of the principle of analogy leads us into an aporetical position about the Resurrection: We must then suppose that the grave was not empty, without having a sufficient explanation as to how the uniform testimony about the empty grave came into being. We could put it as follows: The principle of analogy breaks into pieces in confrontation with the Resurrection. But is there reason to be surprised at this? For does the principle of analogy not exclude $a$ priori what Christians have from of old believed to be true, namely that a single, unique and analogyless intervention by God has taken place? Does this not mean that the principle of analogy is unfit for use in the case of alleged unique, single events and interventions by God?

Alvin Plantinga argues this by means of the following example. Imagine that a friend of yours is accused of stealing a precious vase. You remember that he was with you at the moment the theft took place. The judge, however, does not take your alibi into account and convicts your friend to prison. Here I step in, and I offer to make a thorough scientific investigation of the case. You are enthusiastic and you think: Now the truth will show! But it becomes clear quite soon that I refuse to take your memories into account. Moreover, I start from the assumption that your friend cannot be innocent. Would you still appreciate my investigation? Yet this is exactly the way in which historical-critical research approaches the believer, according to Plantinga. Just like the detective rejects memory as a source of knowledge, the strict historian rejects faith and revelation. And just like the detective assumes the guilt of your friend, the historical-critical method assumes beforehand that God would not raise a dead man from the grave (cf. Plantinga 2000:413-414). In this manner, the historical-critical method excludes a source of knowledge (revelation) which is of great importance to the traditional believer and it renders a priori as false that which Christians traditionally believed to be true: That God has raised Christ from the grave. With respect to the Resurrection, then, the believer has every reason to distrust the historical-critical approach. And even the non-believer will have to admit that one can neither prove nor disprove the historicity of the Resurrection by means of the historical-critical method. This is because the axiomatic assumptions of an investigation cannot be questioned within that investigation.

To avoid misunderstandings: I do not argue for altogether abandoning the principle of analogy. When this principle is abandoned, historiography ceases to be a science. But both the historian and those who draw on the results of historical research must be aware of the fact that the principle of analogy a priori excludes unique events such as miracles. In this sense we may speak of methodological atheism. Because of this methodological atheism, alleged miracles or interventions by God fall outside the scope of historical research. In these instances, its results will not be acceptable to the believer. Christians may believe that the axioms of strict historiography, however fruitful they may in many cases be, are not true. Therefore they would expect that in certain cases, where alleged divine interventions are at stake, the application of these axioms will lead to an aporetical position. I have argued that this is the case with the Resurrection.

Once more: Has Christ truly risen or not? In my view, we can best answer this question in terms of a distinction introduced by Karl Barth. Barth distinguished between Geschichte and Historie. Geschichte is the sum of events which took place in the past; Historie is what can be ascertained by the methods of strict historiography, including the principle of analogy. Thus, the events of Historie are a subset of the events of Geschichte. Creation, for example, is Geschichte but not Historie. For creation, according to Barth and other traditional Christian believers, is a fact about the past, and therefore part of Geschichte, but it cannot be explained in terms of innerworldly relations, and therefore it is not part of Historie. Thus, creation is a fact, but not a historical fact. Something similar goes for the Resurrection and all the other miracles that really took place: They are facts, but not historical facts. They took place, but they cannot be explained from inner-worldly relations, as is demanded by the principle of analogy.

This enables us to answer the question whether Jesus truly has risen. The believer will say: Yes, it is Geschichte, it is a fact and it really took place. Anyone who would have been there would have found the grave empty. But the believer will also have to admit that it is not Historie in the strict sense, for it cannot be ascertained by the methods of historical-critical science. Historians, I think, will accept this. They should, however, accept something more: The historical-critical approach ends in a deadlock when applied to the Resurrection, given that it cannot establish what really happened. Moreover, the fact that historical-critical approaches lead to the denial of the Resurrection in the traditional sense is not so much a discovery of historical criticism as the consequence of a basic assumption. Finally, historians should admit that believers have good reason to reject this basic assumption and thus also the application of this principle to alleged unique events and miracles. Thus, the Resurrection is the ultimate miracle, but one needs the eyes of faith to see it.

\section{Acknowledgements Competing interests}

The author declares that he has no financial or personal relationship(s) that may have inappropriately influenced him in writing this article.

\section{References}

Aswin-Siejkowski, P., 2009, The Apostles' Creed: The Apostles' Creed and its early Christian context, T\&T Clark, London.

Barth, K., 1945, Kirchliche Dogmatik III/1, EVZ, Zürich.

Barth, K., 1948, Kirchliche Dogmatik III/2, EVZ, Zürich.

Bultmann, R., 1961, 'New Testament and mythology: The mythological element in the message of the New Testament and the problem of its re-interpretation' (1941) in H.W. Bartsch (ed.), Kerygma and mythos: A theological debate, pp. 1-44, HarperCollins, San Francisco.

Craig, W.L., 1985, 'The historicity of the empty tomb of Jesus', New Testament Studies 31, 39-67. http://dx.doi.org/10.1017/S0028688500012911

De Jonge, H.J., 1989, 'Ontstaan en ontwikkeling van het geloof in Jezus' opstanding', in F.O. van Gennep et al. (reds.), Waarlijk opgestaan: Een discussie over de opstanding van Jezus Christus, pp. 31-50, Ten Have, Baarn. 
Ehrman, B.D., 2012, Did Jesus exist? The historical argument for Jesus of Nazareth HarperCollins, New York.

Hansson, M.J., 1991, Understanding an act of God: An essay in Philosophical Theology, Almqvist \& Wiksell, Uppsala.

Holland, R.F., 1965, 'The miraculous', American Philosophical Quarterly 2, 43-51.

Kretzmann, N., 1993, 'Resurrection Resurrected: Comments on the paper of Adela Yarbro Collins', in E. Stump \& T.P. Flint (eds.), Hermes and Athena: Biblical Exegesis and Philosophical Theology, pp. 141-150, University of Notre Dame Press, Notre Dame.

McGuckin, J.A., 2004, The Westminster handbook to Patristic Theology, Westminster John Knox, Louisville.

Muddiman, J., 1989, 'Biblical Criticism and Truth', Lecture delivered at the annual conference of the Society for the Study of Theology, Oxford, 05 April.

Neill, S., 1964, The interpretation of the New Testament, Oxford University Press, Oxford.

Nienhuis, G., 1995, 'Toeval en voorzienigheid', in A. van de Beek (red.), Lichtgeraakt: Wetenschapsbeoefenaren over de relatie van hun gelovig christen-zijn en hunwerk, pp. 36-50, Callenbach, Nijkerk.
Pannenberg, W., 1967, 'Heilsgeschehen und Geschichte', in W. Pannenberg (Hrsg.), Grundfragen systematischer Theologie: Gesammelte Aufsätze, pp. 22-78, Vandenhoeck und Ruprecht, Göttingen.

Pannenberg, W., 1994, 'Die Auferstehung Jesu: Historie und Theologie', Zeitschrift für Theologie und Kirche 91, 318-328.

Philipse, H., 2001, 'Jezus is waarlijk niet opgestaan', NRC Handelsblad, 23 juni.

Philipse, H., 2012, God in the age of science? A critique of religious reason, Oxford University Press, Oxford. http://dx.doi.org/10.1093/acprof:oso/9780199697533.001.0001

Plantinga, A., 2000, Warranted Christian belief, Oxford University Press, Oxford. http:// dx.doi.org/10.1093/0195131932.001.0001

Schillebeeckx, E.C.F.A., 1979, Jesus: An experiment in Christology, Seabury Press, New York.

Troeltsch, E., 1913, 'Über historische und dogmatische Methode in der Theologie', in E. Troeltsch (Hrsg.), Gesammelte Schriften Il:Zurreligiösen Lage, Religionsphilosophie und Ethik, pp. 729-753, Mohr, Tübingen.

Veldhuis, W.J., 1978, Over Jezus gesproken... Een oud verhaal dat verdergaat, Gooi \& Sticht, Hilversum. 